\title{
Chemical composition of essential oils of Passiflora edulis f. flavicarpa agroindustrial waste
}

\author{
Ivan Chóez-Guaranda ${ }^{1 *}$, Arnold Ortega ${ }^{1}$, Migdalia Miranda², Patricia Manzano ${ }^{1,3}$ \\ ${ }^{1}$ Escuela Superior Politécnica del Litoral, ESPOL, Centro de Investigaciones Biotecnológicas del Ecuador, Campus Gustavo Galindo Km 30.5 \\ Vía Perimetral, P.O. Box 09-01-5863, Guayaquil, Ecuador, ${ }^{2}$ Universidad de Guayaquil, Facultad de Ciencias Químicas, Cdla. Universitaria \\ "Salvador Allende", Malecón del Salado entre Av. Delta y Av. Kennedy, Guayaquil, Ecuador, ${ }^{3}$ Escuela Superior Politécnica del Litoral, ESPOL, \\ Facultad de Ciencias de la Vida, Campus Gustavo Galindo Km 30.5 Vía Perimetral, P.O. Box 09-01-5863, Guayaquil, Ecuador
}

\section{A B S TR A C T}

The study of the chemical composition of essential oils of shells and seeds of Passiflora edulis f. flavicarpa is discussed. The essential oils were obtained by microwave assisted hydrodistillation (MAHD) as extraction method using Clevenger apparatus. The compounds were separated and identified by gas chromatography mass spectrometry (GC-MS). There were no significant differences of essential oil yields between samples. 20 compounds were detected altogether. lonol was the main compound in shells $(13.15 \%)$ and seeds $(12.10 \%)$. Nevertheless, some fatty acid methyl ester, aldehydes, hydrocarbons and other terpenes were found in minor quantities. These results have not been informed previously and allow adding value to this agroindustrial waste.

Keywords: Essential oil; lonol; GC-MS; Residue; Yellow passion fruit

\section{INTRODUCTION}

Yellow passion fruit (Passiflora edulis f. flavicarpa) is one of the most economically important crops of Passiflora species due to quality of the fruit (Zeraik et al., 2010). It is cultivated widely in tropical and semitropical regions all over the world and it is mainly used for production of concentrated juice and frozen pulp (Deng et al., 2010). Nonetheless, these processes generate a large amount of residues such as shells and seeds that represent additional operational costs and environmental issues (Leão et al., 2014; Oliveira et al., 2016).

A yellow passion fruit has approximately $58 \%$ of juice and $42 \%$ of residues altogether (FAO, 1997), whose corresponds around $34 \%$ of shells and $8 \%$ of seeds (Ayala and Cevallos, 2013). Hence, if in the first months of 2015 Ecuador exported 6,034 Tons of juice solely to Netherlands (PROECUADOR, 2015), it can be inferred that approximately 4,369 tons of residues which contains shells and seeds were produced in this period.

Even though there is a great amount of generated waste as shells and seeds, some studies have shown that these residues can be reused. Seeds have been used to extract oil by mechanical press and the seed cake obtained in this process has showed a high content of lipids with significant unsaturated fatty acids (Oliveira et al., 2016; Silva et al., 2015). In fact, fruit extracts and seed oil that contain tocopherols and phenolic compounds have been showed 2,2-diphenyl-1-picryl hydrazine (DPPH) scavenging capacity (Silva et al., 2015; Malacrida and Neuza, 2012). On the other hand, shells which are rich in fiber have been used to elaborate flour with stabilizing, emulsifying, thickening and gelling power properties similar to commercial hydrocolloid agents use in ice cream and structured fruits (Monteiro et al., 2017). Besides, they have been used to extract pectin with a high esterification degree and galacturonic acid content usefull in the food industry (De Oliveira et al., 2015).

Actually there are no studies about the chemical composition of essential oils of these residues. However, it is known that the aroma of conventional passion fruit is due to the presence of main volatile constituents as ethyl caproate and butyrate, limonene and 2-tridecanone (Dhawan et al., 2004). Therefore, the aim of this study

\footnotetext{
*Corresponding author:

Ivan Chóez-Guaranda, Escuela Superior Politécnica del Litoral, ESPOL, Centro de Investigaciones Biotecnológicas del Ecuador, Campus Gustavo Galindo Km 30.5 Vía Perimetral, P.O. Box 09-01-5863, Guayaquil, Ecuador. E-mail: iachoez@espol.edu.ec
} 
was to characterize the essential oils of shells and seeds of Passiflora edulis f. flavicarpa through GC-MS in order to provide potential food applications to this agricultural waste, improve the supply chain and provide positive impact on the environment.

\section{MATERIALS AND METHODS}

\section{Raw material}

The raw materials used in the present study were obtained from fruits that were collected in a juice and frozen processing company in Quevedo city (Los Rios, Ecuador). The fruits were classified according to their size following the NTE INEN 1910:2012 standard. Afterward, were washed and went through by different separations processes to obtain shells and seeds prior to extraction procedure.

\section{Microwave assisted hydrodistillation (MAHD)}

The procedure used for the extraction of essential oils of shells and seeds of Passiflora edulis flavicarpa was fitted from the method described by Rodríguez et al. (2012). Microwave assisted hydrodistillation system with Clevenger apparatus was used for extraction. Fresh raw material was distilled with water at $100^{\circ} \mathrm{C}$ and atmospheric pressure for four consecutive cycles of 10 minutes. The essential oils were separated with diethyl ether, were dried with anhydrous sodium sulfate, were weighed and stored in amber vials until GC-MS analysis.

\section{Gas chromatography mass spectrometry (GC-MS)}

GC-MS analysis were carried out by a gas chromatography mass spectrometry equipment Agilent Technologies (7890A GC system and 5975C inert XL MSD with triple axis detector). A capillary column HP-5MS $(30 \mathrm{~m} \times 0.25 \mathrm{~mm})$ with phenyl methylpolysiloxane was used as stationary phase $(0.25$ micron film thickness) and helium as the carrier gas $(0.9 \mathrm{~mL} / \mathrm{min})$. The injection of $0.5 \mu \mathrm{L}$ of sample ( $5 \mathrm{mg} / \mathrm{mL}$ for seeds and $100 \mathrm{mg} / \mathrm{mL}$ for shells) diluted in diethyl ether was done at a temperature of $250^{\circ} \mathrm{C}$ with splitless mode, the detector temperature was $280^{\circ} \mathrm{C}$ and the oven temperature was maintained at $50^{\circ} \mathrm{C}$ for 0.5 minutes, then it was increased to $250^{\circ} \mathrm{C}$ at $4^{\circ} \mathrm{C} / \mathrm{min}$. The electron ionization to $70 \mathrm{eV}$ and $230^{\circ} \mathrm{C}$ was used as ion source and the data compounds were collect with the full scan mode (40-1000 uma) in the quadrupole mass analyzer. After all, compounds were identified by comparison of their mass spectra and mass reference of Wiley $9^{\text {th }}$ with NIST 2011 MS Library.

\section{Statistical analysis}

Yield experiments were carried out in triplicate for each sample and data were expressed as means \pm standard deviation. Differences were evaluated by the one-way analysis of variance (ANOVA), and comparison among means was determined according to Tukey test with 5\% significance using InfoStat statistical software, version 2008 (Balzarini et al., 2008).

\section{RESULTS AND DISCUSSION}

The results of MAHD and GC-MS analysis of essential oils of yellow passion fruit shells and seeds are presented below.

The yield percents of extracted essential oils are shown in Table 1. These results have not been referenced. The essential oil of shells $(0.02222 \%)$ apparently showed to be the highest in comparison with seeds $(0.01450 \%)$. Nonetheless, according to the comparative analysis there are no significant differences between samples. Probably, this is because the concentration of the samples, dispersion of the yield data obtained and the number of replicates used for each experiment. Despite the statistical outcome, these results indicate that essential oils of shells have the biggest quantity of volatile compounds. On the other hand, MAHD technique was used as extraction procedure because is superior in terms of saving energy and extraction time compared with conventional hydrodistillation. Even, GC-MS analysis of extracted essential oils indicated that the use of microwave irradiation didn't influence in the composition of the essential oils (Golmakani and Rezaei, 2008). Nonetheless, many investigations demonstrate that conventional hydrodistillation have shown higher yields than supercritical fluid extraction (SFE), microwave assisted hydrodistillation (MAHD) and solid phase micro extraction (SPME) (Omán et al., 2013). Thus, the low yield percentages obtained in this work could be explained by the extraction method employed.

The chromatograms of Fig. 1 show the chromatographic profile of essential oils of yellow passion fruit shells (a) and seeds (b). The chemical composition of the essential oils of yellow passion fruit shells and seeds are shown in Table 2, where they are listed in order of elution. Totally, 20 compounds were identified in two essential oils: 2 monoterpenes, 2 sesquiterpenes, 2 aldehydes, 6 esterified fatty acids and 8 hydrocarbons. Although most components were the same for both samples and they were formed by esterified fatty acids and hydrocarbons, the dominant

Table 1: Yield percents of essential oils of shells and seeds of Passiflora edulis $\mathrm{f}$. flavicarpa

\begin{tabular}{lc}
\hline Sample & Yield (\%) \\
\hline Shells & $0.0222200 \pm 0.0105027^{a}$ \\
Seeds & $0.0144967 \pm 0.0029120^{a}$ \\
\hline
\end{tabular}

Means values $(n=3) \pm$ standard deviation, a Different letters indicate significant differences between samples according to Tukey test $(p \leq 0.05)$ 


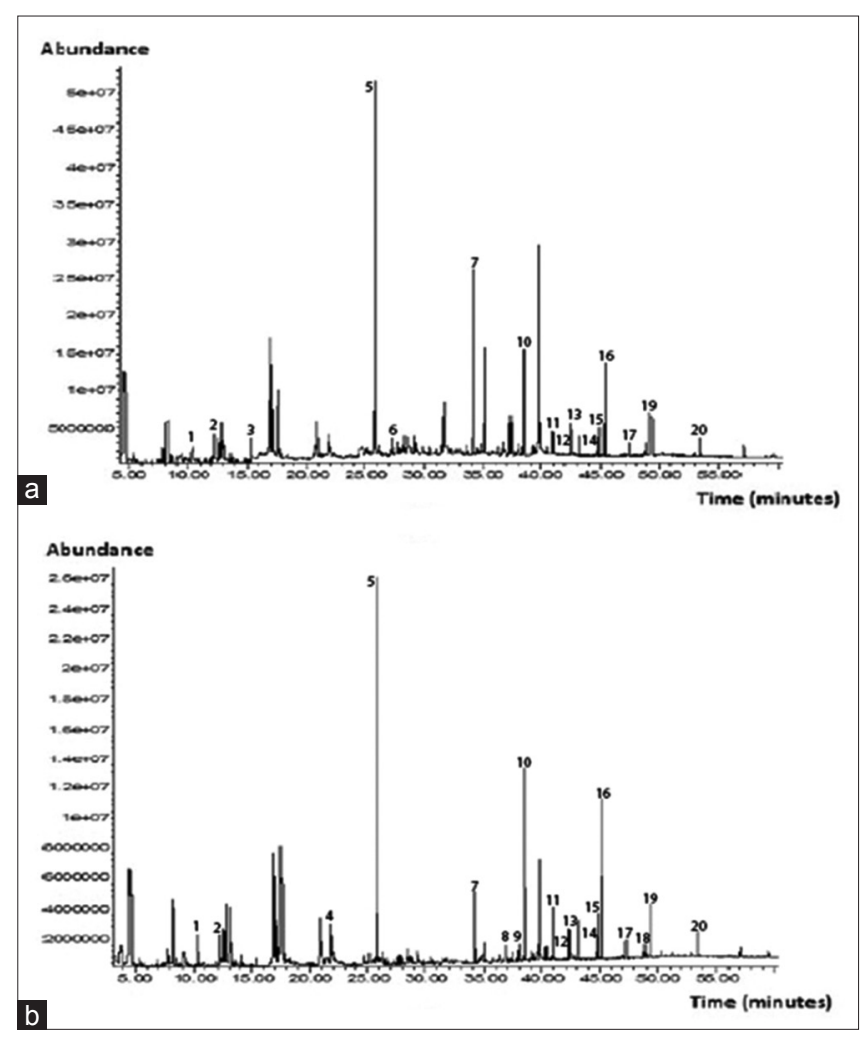

Fig 1. Chromatographic profiles of essential oils of shells (a) and seeds (b) of Passiflora edulis f. flavicarpa obtained by GC-MS.

Table 2: Chemical composition of essential oil of shells and seeds of Passiflora edulis f. flavicarpa

\begin{tabular}{lclcc}
\hline Peak & $\begin{array}{c}\text { Retention } \\
\text { time }(\mathbf{m i n})\end{array}$ & Compound & \multicolumn{2}{c}{ Peak area \% } \\
\cline { 4 - 5 } & Shells & Seeds \\
\hline 1 & 10.295 & Benzeneacetaldehyde & 0.83 & 1.69 \\
2 & 12.197 & Linalool & 1.06 & 0.89 \\
3 & 15.335 & $\alpha$-Terpineol & 0.65 & ND \\
4 & 21.817 & Hexyl caproate & ND & 1.16 \\
5 & 25.780 & lonol & 13.15 & 12.10 \\
6 & 27.251 & d-Nerolidol & 0.88 & ND \\
7 & 34.133 & Palmitaldehyde & 6.24 & 2.18 \\
8 & 36.875 & Methyl Palmitate & ND & 0.51 \\
9 & 38.008 & Ethyl 9-Hexadecenoate & ND & 0.51 \\
10 & 38.523 & Ethyl Palmitate & 3.56 & 5.79 \\
11 & 40.941 & Heneicosane & 0.83 & 1.66 \\
12 & 42.340 & Ethyl Linoleate & 1.00 & 0.98 \\
13 & 42.474 & Ehtyl Oleate & 0.94 & 0.98 \\
14 & 43.148 & Docosane & 0.78 & 1.29 \\
15 & 44.860 & 9-Tricosene & 0.90 & 1.36 \\
16 & 45.279 & Heptadecane & 3.29 & 5.13 \\
17 & 47.315 & Eicosane & 0.45 & 0.59 \\
18 & 48.925 & 1-Nonadecene & ND & 0.41 \\
19 & 49.275 & Pentacosane & 1.46 & 1.74 \\
20 & 53.404 & Octadecane & 0.89 & 1.08 \\
\hline
\end{tabular}

ND: Not detected

compound was ionol. This cyclic sesquiterpen showed the highest area percent in shells $(13.15 \%)$ and seeds $(12.10 \%)$. These results are similar to previous studies for essential oils of Passiflora ligularis Juss, where ionol was the main compound for shells and one of the majorities in seeds (Chóez et al., 2015). Also, It was reported as a volatile compound of yellow passion fruit flavor for the first time in 1998 (Werkhoff et al., 1998). Hence, these findings prove that ionol is a distinctive compound existing in some essential oils of Passiflora species.

Even though the yields of essential oils are pretty low it should be considered the high amounts of cultivated fruits and waste generated (PROECUADOR, 2015), in order to take advantage of the identified compounds. In this context, it will be presented some food and pharmacological applications of the main substances.

Ionol could be used as food additive. In fact, it was approved as flavouring agent by World Health Organization (WHO) because it wasn't showed health risks. This sesquiterpen and other related derivatives compounds weren't exceed the threshold for human intake (1800 ug per day) and they metabolized to innocuous products (WHO, 1998).

It is evident that ionol was the main compound in two samples. However, palmitaldehyde (6.24\%) presented the second higher area percent in shells but no in seeds. The esterified fatty acid ethyl palmitate $(5.79 \%)$ and the hydrocarbon heptadecane $(5.13 \%)$ showed to be the second major compounds in seeds indeed.

Heptadecane has been identified in minor amounts in organic and conventional passion fruit pulp (Macoris et al., 2011). Palmitaldehyde was detected in shells and seeds, this fatty aldehyde has been reported previously in essential oil of Passiffora ligularis Juss juice and it was showed to be one of the major volatile compounds of this specie too (Chóez et al., 2015). Another aldehyde found was benzeneacetaldehyde, this compound has been reported in yellow passion fruit (Jordán et al., 2000) and it is known as a key odor compound that plays a central role in pollinator attraction and floral isolation (Falcão et al., 2008).

On the other hand, the esterified fatty acid ethyl palmitate has been used as flavoring ingredient in foods and it is listed in the Encyclopedia of Food and Color Additives indeed (Burdock, 1997). Also, ethyl 9-hexadecenoate has been reported as additive for alcoholic beverages, specifically in the whiskey industry (Nykänen and Suomalainen, 1983) and methyl palmitate has been demonstrated antiinflammatory and antifibrotic effects in experimental animal models of liver injury (Cai et al. 2005; RodriguezRivera et al. 2008). Furthermore, methyl palmitate has been combated inflammation in several models of inflammatory disorders such as: paw edema, lipopolysaccharide-induced endotoxemia, lipopolysaccharide-induced acute lung injury 
and croton oil-induced ear edema in rats (Saeed et al. 2012; Sharawy et al. 2013). Moreover, is one of the best known ligands for pheromone receptors Or47b and Or88a (Dweck et al. 2015). This last compound was detected only in seeds. These results coincide with the finding of essential oils of Passiflora ligularis Juss where methyl palmitate showed to be present as a volatile constituent of seed essential oil of this Pasiffora specie. Neither in shells nor juice it wasn't detected (Chóez et al., 2015). In addition, ethyl 9-hexadecenoate was detected just in seeds too. On the contrary, it has been detected in aerial parts of Passiffora incarnate L. methanolic extract (Aman et al., 2016).

Equally important, hexil caproate $(1.16 \%)$ was detected in minor quantities just in seed essential oil. This fatty ester has been described as the majority volatile compound of passion fruit juice (Hiu and Scheuer, 1961) and it is used in fragrances of soap, detergent, cream, lotion and perfumes. Additionally, it is utilized as artificial flavoring of foodstuffs and it has been approved by the Food and Drug Administration (FDA) for food use (Opdyke, 1978).

Alternatively, the high presence of aliphatic compounds with minor peak area percents such as heneicosane, docosane, 9-tricosene, eicosane, 1-nonadecene, pentacosane and octadecane could be explained by the gums and/or resins of vegetal matrixes. These compounds are freed from such products by distillation (Hüsnü et al., 2007). The results indicate that peak area of esterified fatty acids with the exception of ethyl linoleate were higher in seeds. In fact, the three esterified fatty acids that elute first weren't identified in shells. In the same way, the long-chain alkanes have been showed a similar relation but 1 -nonadecene wasn't detected in shells.

Instead of the low presence of monoterpens and sesquiterpens in both samples, linalool was identified in shells $(1.06 \%)$ and seeds $(0.65 \%)$ but $\alpha$-terpineol $(0.65 \%)$ and d-nerolidol $(0.88 \%)$ were detected only in shells. So, it can be inferred that these last compounds are characteristics of this residue. Linalool has been described in tropical fruits such as passion fruit and banana (Jordán et al., 2000). Even it has been reported as one of main compounds of essential oil of Passiffora incarnate L (Buchbauer and Jirovetz, 1992) and it has been informed as molluscicidal, larvicidal (Yang et al., 2014), analgesic, anti-inflammatory and antioxidant (Seol et al., 2016). Equally important $\alpha$-terpineol has been described as one of the major flavor constituents of yellow passion fruit (Hui et al., 2010), this terpene is responsible of the floral aroma of passion fruit and it is considered as a marker volatile compound (Janzantti and Monteiro, 2014; Conde-Martínez et al, 2014). Further, it has reported significant biological activities such as antimicrobial, antispasmodic, anticonvulsant and antinociceptive immunostimulant (Oliveira et al., 2016). It is considerable to mention that linalool and $\alpha$-terpineol have been described before as aroma compounds for organic passion fruit. In fact, the abundance of these terpene alcohols increased in the ripeness process of the pulp (Janzantti and Monteiro, 2014).

\section{CONCLUSIONS}

These findings suggest that essential oils of Passiflora edulis f. flavicarpa shells and seeds might be useful as raw material for food additive due to the properties previously reported of the main constituents ionol and ethyl palmitate. These two essential oils could be used as flavor and aroma substances in the food industry. Additionally, in accordance to outcomes the cyclic sesquiterpen ionol showed to be a maker volatile compound of these agroindustrial waste essential oils.

\section{ACKNOWLEDGEMENTS}

The authors are gratefull to the Ecuadorian Science and Technology Secretariat (SENESCYT), who was provided the funding through the National program PROMETEO.

\section{Author contributions}

I. C. G. and M. M. M. designed, conducted the work and wrote the paper, A. O. made the experimental work and P. I. M. S. made a major contribution to the review paper.

\section{REFERENCES}

Aman, U., F. Subhan, M. Shahid, S. Akbar, N. Ahmad, G. Ali, K. Fawad, R and D. E. Sewell. 2016. Passiflora incarnata attenuation of neuropathic allodynia and vulvodynia apropos GABA-ergic and opioidergic antinociceptive and behavioural mechanisms. BMC Complement. Altern. Med. 16: 77.

Ayala, A. and E. Cevallos. 2013. Plan de exportación de concentrado de maracuyá ecuatoriano al mercado japonés. Tesis de Ingeniería Comercial Con Mención en Comercio Exterior, Universidad Politécnica Salesiana, Guayaquil, EC.

Balzarini, M. G., L. Gonzalez, M. Tablada, F. Casanoves, J. A. Di Rienzo and C. W. Robledo. 2008. Infostat. Manual del Usuario, Editorial Brujas, Córdoba, Argentina.

Buchbauer, G. and L. Jirovetz. 1992. Volatile constituents of the essential oil of Passiflora incarnata L. J. Essent. Oil Res. 4: 329-334.

Burdock, G. A. 1997. Encyclopedia of Food and Color Additives, CRC Press, Boca Raton, FL, pp. 1029-1030.

Cai, P., B. S. Kaphalia and G. A. Ansari. 2005. Methyl palmitate: Inhibitor of phagocytosis in primary rat Kupffer cells. Toxicology. 210: 197-204.

Chóez, I., D. Herrera, M. Miranda and P. Manzano. 2015. Chemical composition of essential oils of shells, juice and seeds of Passiflora ligularis juss from ecuador. Emir. J. Food Agric. 27: 650 . 
Conde-Martínez, N., D. C. Sinuco and C. Osorio. 2014. Chemical studies on curuba (Passiflora mollissima (Kunth) L. H. Bailey) fruit flavour. Food Chem. 157: 356-363.

Deng, J., Y. Zhou, M. Bai, H. Li and L. Li. 2010. Anxiolytic and sedative activities of Passiflora edulis f. Flavicarpa. J. Ethnopharmacol. 128: 148-153.

Dweck, H. 2015. Pheromones mediating copulation and attraction in Drosophila. Proc. Natl. Acad. Sci. USA. 112: E2829-E2835.

De Oliveira, C. F., D. Giordani, P. D. Gurak, P. D. F. Cladera-Olivera and L. D. Ferreira. 2015. Extraction of pectin from passion fruit peel using moderate electric field and conventional heating extraction methods. Innov. Food Sci. Emerg. Technol. 29: 201-208.

Dhawan, K., S. Dhawan and A. Sharma. 2004. Passiflora: A review update. J. Ethnopharmacol. 94: 1-23.

Falcão, L. D., G. de Revel, J. P. Rosier and M. T. Bordignon-Luiz. 2008. Aroma impact components of Brazilian cabernet sauvignon wines using detection frequency analysis (GC-olfactometry). Food Chem. 107: 497-505.

FAO. 1997. Small-scale processing of fruits and vegetables amazonian native and introduced. Technical Manual, Amazon Cooperation Treaty, Food and Agriculture Organization of the United Nations Regional Office for Food Technology and Agroindustry, Lima, Perú.

Golmakani, M. T. and K. Rezaei. 2008. Comparison of microwaveassisted hydrodistillation with the traditional hydrodistillation method in the extraction of essential oils from Thymus vulgaris $L$. Food Chem. 109(4): 925-930.

Hiu, D. N. and P. J. Scheuer. 1961. The volatile constituents of passion fruit juice. J. Food Sci. 26: 557-563.

Hui, Y. H., F. Chen and L. M. L. Nollet. 2010. Handbook of Fruit and Vegetable Flavors, John Wiley and Sons, New York, pp. 476-479.

Hüsnü, K., C. Başer and F. Demirci. 2007. Chemistry of essential oils. In: Flavours and Fragrances, Springer Berlin Heidelberg, New York, NY, pp. 43-86.

Janzantti, N. S. and M. Monteiro. 2014. Changes in the aroma of organic passion fruit (Passiflora edulis Sims f. Flavicarpa Deg.) During ripeness. LWT Food Sci. Technol. 59: 612-620.

Jordán, M. J., K. L. Goodner and P. E. Shaw. 2000. Volatile components in tropical fruit essences: Yellow passion fruit (Passiflora edulis Sims f. Fiavicarpa Degner) and banana (Musa sapientum L.). In: Proceedings of the $113^{\text {th }}$ Annual Meeting, Lake Buena Vista, Florida, pp. 284-286.

Leão, K. M., K. L. Sampaio, A. A. Pagani and M. A. A. Da Silva. 2014. Odor potency, aroma profile and volatiles composition of cold pressed oil from industrial passion fruit residues. Ind. Crops Prod. 58: 280-286.

Macoris, M. S., N. S. Janzantti, D. D. S. Garruti and M. Monteiro. 2011. Volatile compounds from organic and conventional passion fruit (Passiflora edulis F. Flavicarpa) Pulp. Food Sci. Technol. Camp. 31: 430-435.

Malacrida, C. R. and J. Neuza. 2012. Yellow passion fruit seed oil (Passiflora edulis f. flavicarpa): Physical and chemical characteristics. Braz. Arch. Biol. Technol. 55: 127-134.

Monteiro, E., R. Gutierres, B. Souza, R. Santos, M. dos Santos Lima, L. Cavalcanti de Azêvedo and M. Umsza. 2017. Passion fruit peel flour-technological properties and application in food products. Food Hydrocoll. 62: 158-164.

Nykänen, L. and H. Suomalainen. 1983. Aroma of Beer, Wine and Distilled Alcoholic Beverages, Springer Science \& Business Media, Berlin, p. 177.
Oliveira, D. A., M. Angonese, C. Gomes and S. R. Ferreira. 2016. Valorization of passion fruit (Passiflora edulis Sp.) By-products: Sustainable recovery and biological activities. J. Supercrit. Fluids. 111: 55-62.

Oliveira, M. G. B., R. G. Brito, P. L. Santos, H. G. Araújo-Filho, J. S. S. Quintans, P. P. Menezes, M. R. Serafini, Y. M. B. G. Carvalho, J. C. Silva, J. R. G. S. Almeida, L. Scotti, M. T. Scotti, S. Saravanan, T. Parimelazhagan, A. A. S. Araújo and L. J. Quintana-Júnior. 2016. a-terpineol, a monoterpene alcohol, complexed with $\beta$-cyclodextrin exerts antihyperalgesic effect in animal model for fibromyalgia aided with docking study. Chem. Biol. Interact. 254: 54-62.

Oman, M., M. Škerget and Z. Knez. 2013. Application of supercritical fluid extraction for separation of nutraceuticals and other phytochemicals from plant material. Maced. J. Chem. Chem. Eng. 32(2): 183-226.

Opdyke, D. L. J. 1978. Hexyl caproate, fragrance raw materials monographs. Food Cosmet. Toxicol. 13: 449-457.

Proecuador, 2015. Evolución de Las Exportaciones Ecuatorianas, Enero-Abril 2013-2015, Instituto de Promoción de Exportaciones e Inversiones, Quito, Ecuador.

Rodríguez, R., C. Ruiz, G. Arias, H. Castro, J. Martínez and E. Stashenko. 2012. Estudio comparativo de la composición de los aceites esenciales de cuatro especies del género Cymbopogon (Poaceae) cultivadas en Colombia. Boll. Latinoam. Caribe Plant Med. Aromat. 11: 77-85.

Rodriguez-Rivera, A., M. Galicia-Moreno, K. Reyes-Gordillo, J. Segovia, P. Vergara, M. G. Moreno, M. Shibayama, V. Tsutsumi and P. Muriel. 2008. Methyl palmitate prevents $\mathrm{CCl}(4)$-induced liver fibrosis. J. Appl. Toxicol. 28: 1021-1026.

Saeed, N. M., E. El-Demerdash, H. M. Abdel-Rahman, M. M. Algandaby, F. A. Al-Abbasi and A. B. Abdel-Naim. 2012 Anti-inflammatory activity of methyl palmitate and ethyl palmitate in different experimental rat models. Toxicol. Appl. Pharmacol. 264: 84-93.

Seol, G. H., P. Kang, H. S. Lee and G. H. Seol. 2016. Antioxidant activity of linalool in patients with carpal tunnel syndrome. BMC Neurol. 16: 17.

Sharawy, M. H., D. S. El-Agamy, A. A. Shalaby and E. M. Ammar. 2013. Protective effects of methyl palmitate against silicainduced pulmonary fibrosis in rats. Int. Immunopharmacol. 16: 191-198.

Silva, R. M., G. R. Plácido, M. A. P. Silva, C. F. S. Castro, M. S. Lima and M. Caliari. 2015. Chemical characterization of passion fruit (Passiflora edulis f. Flavicarpa) seeds. Afr. J. Biotechnol. 14: 1230-1233.

Werkhoff, P., M. Güntert, G. Krammer, H. Sommer and J. Kaulen. 1998. Vacuum headspace method in aroma research: Flavor chemistry of yellow passion fruits. J. Agric. Food Chem. 46: 1076-1093.

WHO. 1998. Evaluation of Certain Food Additives: Fifty-First Report of the JOINT FAO/WHO Expert Committeeon Food Additives, World Health Organization, Geneva, Switzerland.

Yang, F., E. Long, J. Wen, L. Cao, C. Zhu, H. Hu, Y. Ruan, K. Okanurak, H. Hu, X. Wei, X. Yang, C. Wang, L. Zhang, X. Wang, P. Ji, H. Zheng, Z. Wu and Z. Lv. 2014. Linalool, derived from Cinnamomum camphora (L.) Presl leaf extracts, possesses molluscicidal activity against Oncomelania hupensis and inhibits infection of Schistosoma japonicum. Parasit. Vectors. 7: 407.

Zeraik, M. L., C. A. Pereira, V. G. Zuin and J. H. Yariwake. 2010. Maracujá: Um alimento funcional. Rev. Bras. Farmacogn. 20: $459-471$. 